\title{
History of a great effort... 100 years fighting to avoid blindness - Asociación para Evitar la Ceguera en México, "Hospital Dr. Luis Sánchez Bulnes" I.A.P.
}

\section{Historia de un gran esfuerzo...100 años luchando para evitar la ceguera - Asociación para Evitar la Ceguera en México, Hospital Dr. Luis Sánchez Bulnes, IAP}

\author{
Valeria Sánchez-Huerta, Rafael Sánchez-Fontán* and Guillermo Salcedo-Casillas \\ Hospital Dr. Luis Sánchez Bulnes, Asociación para Evitar la Ceguera en México, Mexico
}

\begin{abstract}
On August 13, 1918, Dr. José de Jesús González and Dr. José Terrés officially founded the Asociación para Evitar la Ceguera en México, receiving as its initial name: "Board for the Prevention of Blindness in Mexico". It started in a doctor's office located in Donceles street, in the historic center of the city, with the first three doctors of the Association; fundamental pillars of the ophthalmological medical community: Francisco Hinojosa, Rafael Nadal and Manuel Covarrubias. During these 100 years, the Association occupied various physical spaces, and currently is established in Vicente Garcia Torres \# 46 street, where the Dr. Luis Sánchez Bulnes Hospital is located. In addition to its assistance function carried out both in the hospital and through a surgical outreach program for rural communities for cataract and strabismus, the Association has an important commitment with human resources training and with knowledge acquisition through its residency and high specialty plans, as well as the extensive research performed. These first 100 years mark the way forward to reaffirm our goal that willalways be the fight to avoid blindness in Mexico.
\end{abstract}

Key words: Asociación para Evitar la Ceguera en México. Care work. Academic training. Residency. High specialty. Research.

\section{Resumen}

El 13 de agosto de 1918 se conformó la fundación oficial de la Asociación para Evitar la Ceguera en México, recibiendo como primer nombre: Junta para la Prevención de la Ceguera en México por parte del Dr. José de Jesús González y el Dr. José Terrés. Empieza físicamente en un consultorio médico ubicado en la calle de Donceles, en el centro histórico, con los tres primeros médicos de la asociación, pilares fundamentales de la comunidad médica oftalmológica: Francisco Hinojosa, Rafael Nadal y Manuel Covarrubias. A los largo de estos 100 años, la asociación ha ocupado diversos espacios físicos hasta estar donde se encuentra ahora: en la calle Vicente García Torres, $n .^{\circ} 46$, en el mismo sitio en que se encuentra el Hospital Dr. Luís Sánchez Bulnes. Además de su función asistencial que lleva a cabo tanto intra como extramuros a través de sus campañas quirúrgicas de catarata y estrabismo, la asociación tiene un compromiso importante con la formación de

Correspondence:

*Rafael Sánchez-Fontan

Vicente García Torres 46

Col. Barrio San Lucas, Del. Coyoacán

Date of reception: 01-08-2018

Date of acceptance: 15-09-2018

DOI: 10.24875/RMOE.M18000040
Available online: 01-11-2018

RevMex Oftalmol (Eng).2018;92(6):260-264 www.rmo.com.mx the CC BY-NC-ND 
recursos humanos y de nuevo conocimiento a través de su plan de residencia y preparación de alta especialidad, así como la extensa investigación que realiza. Estos primeros 100 años marcan el camino a seguir para reafirmar nuestra meta, que seguirá siendo siempre la lucha para evitar la ceguera en México.

Palabras clave: Asociación para Evitar la Ceguera en México. Labor asistencial. Formación académica. Residencia. Alta especialidad. Investigación.

Man has few opportunities to contemplate greatness and even less to be its architect, and this is one of those rare occasions when a privileged group can achieve it,

to pay tribute to this hospital, to the «anonymous patient», who for years has placed his eyes and his life in our hands.

Dr. Luis Sánchez Bulnes

One hundred years after its founding, the Asociación para Evitar la Ceguera en México (APEC), Dr. Luis Sánchez Bulnes Hospital, IAP, currently remains with its visionary response, which illustrious Mexicans promoted in a pressing need for national health.

Just as today, 100 years ago, in the midst of an effervescent and revolutionary social environment, APEC was founded. This dream came true due to famous Mexicans, such as Dr. José de Jesús González, a prominent ophthalmologist, who manifested during the celebration of the V National Medical Congress, the problem of blindness as "a scourge of the humble Mexican people, proposing the creation of an institution that cared for the population with visual problems". Since then, the vision and mandate to fight against the causes of blindness emerged.

A prominent doctor of our country, a man of great human and scientific virtues, Dr. José Terrés, joined this praiseworthy cause. He saw an imperative need for national visual health, and devoted much of his life to the "creation of an organization that offered free ophthalmological medical assistance to the greatest number of patients belonging to the most vulnerable groups in society, without neglecting research and education, which are indispensable for offering excellent services".

Thus, on August 13, 1918, at four o'clock in the afternoon in Mexico City, the conformation of our institution became a reality: the official foundation of the association, receiving as its first name "Board for the Prevention of Blindness in Mexico".

Since then, Dr. Terrés, as a distinguished man of science, imprinted in the spirit of the association strong values of discipline and rigor in the scientific sense, without forgetting the humanitarian vision of the medical community.
Thus, the objectives of the association were agreed upon, with the ultimate goal of giving "free curative and preventive care for low-income patients with ophthalmological conditions. On the other hand, in order to create a strong binomial of teaching to heal, it was sought as a priority, along with the assistance work, the general education: the teaching of ophthalmological oriented medical professionals, coupled with promoting research, to study the causes that in the country most frequently led to blindness, and to propose the most appropriate measures to suppress them, putting into practice everything in their hands".

Only God knows who was the first patient to cross our doors, which have since remained open to mitigate the pain of those who need us. Surely he never thought that it was he who took the

first step of an endless journey, but what we can assure is that since then, a single obsession dominates us, what and how to do

the best, so this troubled travelers find the benefits that they expect from us.

Dr. Luis Sánchez Bulnes

The history of the association begins physically in a medical office located in the street of Donceles, in the historic center. In this place were the three first doctors of the association, fundamental pillars of the ophthalmological medical community: Francisco Hinojosa, Rafael Nadal and Manuel Covarrubias.

The number of patients was such that, by 1921, the association changed its facilities and relocated to the street of Justo Sierra; later, in the house number 19 of the Arista street; and finally, in 1938 a building was bought on the street of Gómez Farías.

At this moment, "the care and academic work of the association was fully realized, first with the development of scientific weeks and later with update courses".

It was in the decade of 1940 when the first subspecialty services in Mexico began. This is how the ophthalmological family of this association was formed, and from that moment on, we saw the expansion of our vision.

Here we have learned that the existence of man does not have the sole purpose of accumulating material wealth, that our medical vocation is spirit, heart and brain, that his path is hard 
and that the struggle, sacrifice and daily concern for the good of others are mandatory steps to arrive with clean eyes and hands full of ideals and realizations, to the fullness of our being.

Dr. Teódulo M. Agundis

"The ideal was to think about the construction of a modern hospital equipped with all the advances that our specialty demanded". This need was consolidated after 1962, through the acquisition of the properties called El Toro and El Tejocote located in Coyoacán.

On May 30, 1974, the street of Vicente García Torres of the Coyoacán neighborhood witnessed the laying of the first stone of the APEC Hospital, with the presence of Dr. Jorge Jiménez Cantú, Secretary of Public Health and Welfare of Mexico.

It is worth mentioning that this institution has been the protagonist of great events for our country. In 1957, the first ocular pathology laboratory was built in Mexico, under the supervision of Dr. Alfredo Gómez Leal, the most prestigious ocular pathologist in our country. Another fact that must be considered is the foundation, in August of 1980, of the "Experimental surgery laboratory Fundación Ricardo J. Cebada". With this laboratory, a teaching program for residents was initiated, which facilitated the practice of ophthalmologyt surgery, also starting a small bioterium.

Dr. Luis Sánchez Bulnes, a passionate doctor and an oculist of tireless spirit, was the director of the hospital for 37 years and chairman of the board from 1970 to 1984. With a great effort, he created this institution, organizing it in the first place to provide ophthalmological medical care to the most unprotected population in the country; he reorganized the board in 1970 and raised funds through breakfasts in different industrial and social events in Mexico City in order to obtain donations.

On the figure of Dr. Luis Sánchez Bulnes, of whom the hospital bears his name, countless memories can be shared. That is why the Ministry of Health awarded him a Medal and the Fiat Lux distinction, for his professionalism, humanitarianism, and the excellence of his body of work in ophthalmology in Mexico. In the Illustrious Doctors Circle of the Ministry of Health, since October 1994, there is the bust of this great man with profound human values, a visionary doctor of the highest social sense, whose main concern was always the visual health of the afflicted patients.

On October 23, 1990, the extension of Vicente García Torres, known as the "second stage of construction", was inaugurated. At this moment, the institutions current organization was defined, with the formation of 14 branches or highly specialized services such as:
Ophthalmopaediatrics and Strabismus, Glaucoma, Retina, Cornea, Orbit, Eyelids and Lacrimal system, Uveitis and Ocular Inflammatory Diseases, Low Vision, Anterior Segment, Genetics, Ultrasound, Pathology, Microbiology, Electrophysiology and Psychophysics and Neuroophthalmology. In addition to having special services such as: Ultrasound, Pathology, Microbiology, Electrophysiology and Psychophysics.

\section{Out-of-hospital care work}

\section{Campaigns}

On May 1, 1941, the "Foreign Service of the Association" began. A Chevrolet truck was obtained and adaptations were made to it to care for the sick. This ambulance constantly traveled to different states located within the center of the Republic.

From August 1989, the campaigns were resumed in the state of Chiapas and are still carried out today. The surgical treatment is performed by the medical staff of the hospital, with equipment and cutting-edge technology and is completely free.

In 1994 a trailer was obtained as a donation and it was converted to an operating room with 6 surgical tables.

Currently, surgery campaigns are carried out in Mexico City in peripheral modules. Outpatient surgery is carried out in different states such as Oaxaca, Durango, Morelia, Guanajuato and others in the center of the country. Each campaign involves eight doctors and five nurses.

\section{Inpatient care work}

\section{Medical care}

In 2017, APEC, Dr. Luis Sánchez Bulnes Hospital, recorded 49,830 first-time consultations, a total of 47,656 subsequent consultations and 136,062 specialty consultations. Regarding surgeries, 10,717 surgical procedures were performed.

\section{Research}

The main objective of the Research Department is to position APEC at the highest levels of competitiveness and technology. Currently, the research areas are Cell Biology and Translational Ophthalmology, Immunology, Molecular Biology and Genomics, and Cellular Neurophysiology and Membrane Biophysics. 


\section{Asociación Para Evitar la Ceguera en México, Hospital Dr. Luis Sánchez Bulnes Certification}

The APEC is certified by the General Health Council, which guarantees the safety standards of all services and the dignified treatment of all hospital users.

\section{Education}

\section{«Teaching to heal...»}

Teaching, a fundamental pillar of our institution, started in the headquarters of Gómez Farías n. 19 and continues today. In 1946, doctors learned ophthalmology observing over the shoulder of the head of service and assisting in surgery. Dr. Alfredo Gómez Leal promoted and strengthened the teaching activity of our Institution, under the idea of being a university hospital.

\section{Manuel Covarrubias Ophthalmological Society}

\section{Scientific and academic community of the Asociación para Evitar la Ceguera en México}

This society was founded on October 6, 1941. It was born from the idea of forming a medical society representative of the association, in order to stimulate the scientific and academic production of its doctors. With this society, the teaching activity of our association began.

It is named after Dr. Manuel Covarrubias, the first APEC graduate (1918). Since its origins, the Manuel Covarrubias Ophthalmological Society aims to stimulate the scientific and academic development of our doctors.

In 1943, Dr. Luis Sánchez Bulnes organized the First Scientific Week of the Association to commemorate the $25^{\text {th }}$ anniversary of our foundation.

These meetings evolved to the Hospital Update Courses that, from 1957 to date, are presented annually, with an average attendance of more than 400 physicians.

As part of the teaching activities, a general plenary session is held, in which residents and interns present interesting or complicated cases. Since 1965, we have hosted postgraduate courses in ophthalmology at the Universidad Nacional Autónoma de México (UNAM).
In 2002, Dr. Daniel Ochoa Contreras, a physician assigned to the Retina Service, began a great transformation of the traditional teaching programs, implementing a rotation of residents every year throughout all hospital services.

In January 2017, Dr. Valeria Sánchez Huerta was appointed as Head of Education, and currently is dedicated to consolidating the existing programs to adapt them to the changes that occur in education systems.

\section{Residents program of the Asociación para Evitar la Ceguera en México}

The APEC offers the residence for specialization in Ophthalmology with a duration of 3 years with UNAM certification. As well as the high specialty graduate course.

Our doctors receive training with the most modern equipment in diagnostic procedures and in the most advanced surgical techniques.

First-year residents (R1) learn diagnosis, clinical exploration and introduction to surgery; second year residents (R2), differential diagnosis and normal surgeries of all kinds; third-year residents (R3), analysis of difficult cases, treatment, complicated case sưrgeries and rehabilitation assessment.

Our tutorial program is lineal: R3, fellow, staff and head of service.

\section{The Asociación para Evitar la Ceguera en México today}

At the centennial, we celebrate for the first time with a Genetics Course and the Centennial Congress.

On August 8 of this year, the Genetics Pre-Congress Course "The Eye in the Diagnosis of Genetic Diseases" was held in the Main Auditorium "Alfredo Gómez Leal". With an attendance of 185 participants including geneticists and ophthalmologists from different medical institutions.

From August 9-11, 2018 we celebrated the LV Update Course in Ophthalmology: «A century of progress. Ophthalmology from today to the future" at the Camino Real Hotel in Polanco in Mexico City, where 685 ophthalmologists participated, who experienced with great joy this historic moment for APEC.

The APEC in Mexico, Dr. Luis Sánchez Bulnes Hospital, IAP, is one of the most important healthcare institutions in the country, a global reference in ophthalmology, since, in addition to having state-of-the-art technology to diagnose and offer a better treatment to 
patients, has a great team of ophthalmologists, who comprise of a large medical and scientific community, and who have not forgotten the values and pillars of our association: providing medical care to the most needy in our country, teaching and research.

Today, APEC is an exemplary institution in the development of the ophthalmological specialty and has managed to be a model hospital in efficiency and quality of the services provided to patients, offering humanitarian and courteous services, timely and with cutting-edge technology We hope to continue on this great journey, in "the art of making ophthalmology", a gift inherited by our predecessors: great teachers and ophthalmologists. Now we can proudly say that, after 100 years of effort, which was initially a group of friends and later something similar to a family, has established itself as an avant-garde ophthalmology hospital that has fought for visual health, especially for the most unprotected Mexicans. Every day we are a growing part of the development of ophthalmology both in the clinical-surgical area and in research and, despite the economic ups and downs, we have always remained faithful to a strictly assistance work, because in 2018 we are only 100 years old, but our goal will always remain the fight to avoid blindness in Mexico.

"The Association is a legend full of names and deeds that would ennoble the most demanding Care Institution. It is an example of iron will converted into action, by the two great engines that have made it immortal. Doctors of yesterday and today forged in the spirit of service, pillars of our fight against human pain..." Dr. Luis Sánchez Bulnes 